\title{
陸屋根上に発生する円錐渦と非定常圧力特性に関するLES解析 LES ANALYSIS FOR A CONICAL VORTEX AND UNSTEADY PRESSURE CHARACTERISTICS ON A FLAT ROOF
}

\author{
小野佳之*，田村哲郎**，片岡浩人*** \\ Yoshiyuki ONO, Tetsuro TAMURA and Hiroto KATAOKA
}

\begin{abstract}
The purpose of this paper is to investigate the motion of the conical vortex which lead to the lange level of the negative pressure near the leading corner by LES analysis when flow attack oblique to the flat roof. First the present LES model is validated for the prediction of the pressure characteristics on the roof through comparison with the experimental data. Next, we study the pressure characteristics associated with the motion of the conical vortex in uniform and turbulent flows by using the computed results. As a result, it is clarified that the flow structures near the stagnation point rapidly change by the characteristics of uniform and turbulent flows and result in the strong conical vortex associated with large suction on a roof.
\end{abstract}

Keywords : LES, conical vortex, peake pressure, low-rise building, LES，円錐渦，ピーク負圧，低層構造物

\section{1. はじめに}

陸屋根に風が斜めから当たる場合、屋根面上に一対の円錐渦が形成 され、軒先付近に強い負圧が作用寸る。この強、負圧は、強風時の屋 根被害の一要因となる恐れがあることから、これまで実測や風洞実験 によりピーク值や発生領域に関して多くの調査が行われてきた。その 結果、実測 1においては風が斜めからの当たる場合に軒先付近に風洞 実験と比べて非常に大きな瞬間的な負圧が発生することが明らかと されている。ただし、瞬間的なピーク負圧は、発生が局部的で外装材 の受圧面積に比べて十分に小さい場合には、外装材全体に作用する風 力には大きくは影響しないことも考えられる。すなわち、瞬間的なピ 一ク負圧に対しては、ピーク值そのものばかりではなく近接領域におう ける発生の同時性への配慮が求められる。一方、風圧実験において観 測される程度の強い負圧は、負圧レベルは実測と比べて小さいものの、 相関性の強い領域が下流側に延びていることが示されており2)、これ により強い負圧が軒先付近の領域に同時に作用することが推測され る。したがって、この同時性をもって作用する強い負圧の特性やそれ をもたらす要因を把握しておくとことは耐風設計上重要である。

風が斜めから当たる時の屋根面に作用する風圧力特性に関して、 河井ら 2,3,4, 5)は、多点の風圧実験により詳細に調べている。その結果、
一様流中では、負圧のレベルが時間の経過とともに急変する圧力レベ ルのスイッチが生じることを見出している。それに対し、境界層乱流 中においては、圧力レベルのスイッチは認められず、軒先に瞬間的で 大きなピーク負圧が作用することが明らかにされている。

このような接近流の特性に依存した強い負圧をもたらす要因に関 しては、Kawai4,6),7や谷口・谷池ら 8,9)により調べられている。谷口・ 谷池 8)は長時間の可視化実験により一様流中における円錐渦の挙動に つい考察し、屋根面上に一対の円錐渦が常に存在するわけではなく、 時として片方が消える渦のスイッチング現象が生じることを報告し ている。さらに、谷池ら 9は、この渦のスイッチングと圧力レベルの スイッチングの関連性を風圧実験や可視化実験により調べている。た だし、屋根面に認められる渦と強い負圧の関係が一貫しない場合があ ることから、風圧・可視化を合わせた考察が必要であることを指摘し ている。

一方、境界層乱流中の瞬間的な強い負圧に関して、谷池ら 10)は、野 外観測により調べている。その結果、軒先のピーク負圧は風向変化と 関連して生じることを示している。Kawaið)は風洞実験により屋根か ら離れた風上の参照点の風速と屋根面の風圧の時刻暦を比較してい る。その結果、ピーク負圧が生じる際には、スケールの大きな乱れが
* (株大林組技術研究所流体研究室 博士 (工学)

** 東京工業大学大学院総合理工学研究科 教授. 工博

*** 株大林組技術研究所流体研究室 グループ長・博士 (工学)
Technical Research Institute Obayashi Corp., Dr. Eng.

Prof., Tokyo Institute of Technology, Dr. Eng.

Group Leader, Technical Research Institute Obayashi Corp., Dr. Eng. 
斜め 25 度付近から作用し、風上側面の正圧が上昇することを明らか にしている。また、屋根面風上における断面の風速分布から、ピーク 負压の発生時には、剥離速度が増加し、円錐渦の循環が強まることを 示している。このように、境界層乱流中のピーク負圧発生時の接近流 の特性や屋根面上の円錐渦の特性が報告されている。ただし、風速測 定の参照点は屋根から離れており、その数も十分ではない。また、屋 根面上の風速測定もある断面に限られており、スケールの大きな乱れ が作用した時に、構造物近傍でどのような流れの空間構造が生じ、空 間的に同時性をもったピーク負圧が発生するのかに関しては明瞭に は示されている訳ではない。特に、円錐渦の特性に関しては、流れの 測定位置が必ずしも一致していないこともあり、Marwood ら 11) Kawaiðによるとピーク負圧発生時においては、屋根面上に発生する 円錐渦のサイズが大きくなることが明らかにされているが、Banks ら 12)の風圧と可視化の同時測定に基づく考察によると、境界層乱流中 においては、負圧のレベルと円錐渦のサイズの相関は得られていない。 そのため、ピーク負圧発生時の円錐渦の振る舞いに関しては、さらに 詳細な検討が必要と考えられる。

以上のように、接近流により複雑に変化する円錐渦の挙動に関して は、風圧・可視化実験により行われてきた。しかし、風洞実験ではピ 一一負圧に関連する軒先近傍の流れの空間構造を特性を把握するの は容易ではない。一方、流れと風圧力特性の関連性を検討寸る有効な 手段として、近年急速に発展している流体計算手法が挙げられる。著 者らは、非定常計算手法である LES を用いて、高層構造物の空力特 性や空力不安定振動やそれに及ぼす接近流の影響の物理機構に関し て、流れの可視化を用いて検討してきた 13),14),155。低層構造物まわり流 れへの LES 手法の適用により、実測や実験で検討に限界があった軒 先近傍の流れの空間構造に基づき、強い急圧をもたらす要因をより明 瞭にできるものと期待できる。

本研究では、風が斜め 45 度から陸屋根に当たった時の同時性をも って作用する強い負圧をもたらす円錐渦の挙動を明らかにすること を目的とし、低層構造物まわりの流れの LES 解析を行う。一方、 1 994 年に実施された 1.0:1.0:0.5（=幅 : 奥行き : 高さ）の角柱の屋 根面の風圧特性に関する流体計算と風洞実験の結果の相互比較 16 に よると、定常解析法が多く適用されでいたこともあり、流体計算によ る屋根面上の風圧特性の予測精度は必ずしも満足の行くものとはな っていない。また、屋根面に斜め 45 度から風が作用した時の円錐渦 のゆらぎの挙動および局所負圧の大きさに関しては、非定常解析手法 である LES 解析においても十分には捉えられていない。その要因の1 つとして、円錐渦の挙動をとらえるための格子解像度の不足が挙げら れている。そこで、本計算では、一般座標系 LES ならびに、複数の 格子を重孙合わせる重合格子を採用し、屋根面付近に合理的に格子解 像度を確保する。はじめに、一様流中および境界層乱流中の角柱の屋 根面の風圧特性に関して、計算結果と既往の実験結果 ${ }^{16)}$ と比較し、本 LES 手法の適用性を検証する。次に、一様流中における屋根面近傍の 流れと圧力特性の関係を調べ、既往の研究で観測されてきた圧力レベ ルのスイッチがどのような円錐渦の挙動によりもたらされるのか示 す。最後に、境界層乱流中で同時性をもって作用するピーク負圧が生 じる際の構造物近傍の流れに関して考察し、既往の風圧実験結果によ る知見と比較しながら、ピーク負圧が生じる際の流れの空間構造を示 す。

\section{2. 計算手法}

流体の支配方程式は一般座標で表された非圧縮性の Navier・ Stokes 方程式と連続の式である。計算アルゴリズムは, フラクショ ナル・ステップ法に基づく。 時間積分は, クランク・ニコルソン法 を用いる。空間微分は二次精度の中心差分とし，対流項には高次精 度の補間法 17)を用いる。さらに, 剥離点付近の数值不安定性を除去 する為に小さな数值粘性（UTOPIA の 1/5）を加える。乱流モデルは ダイナミック SGS モデルを用いる。解析手法の詳細は文献 18)を参照 されたい。本研究では、屋根面付近に格子点を集中させることを目的 とし、複数の格子を重站わせる重合格子を用いる。格子間のデータ （速度、圧力）のやりとりは、線形補間を用いた。境界層乱流の生成 には Lund らの方法 19）を改良した片岡の方法 20)を用いた。

\section{3 解析モデルおよび境界条件}

解析モデルは、正方形断面で高さが見附幅の半分の角柱とする。風 向は、屋根に斜めから作用する場合であり、角柱に正対する風向を0 度とすると 45 度である。計算格子は図 1 （分割数は表 1 ）に示すよ うに3つの格子を重祸わせた重合格子とした。角柱の一辺の幅 B と 頂部高さの風速 $\mathrm{U}_{\mathrm{H}}$ を用いて算出したレイノルズ数は、一様流の場合 は 100,000、境界層乱流中のケースでは 20,000 とした。境界条件は 格子 1 の側面および上面は Free-slip 条件、出口は流出境界条件で、 格子 2 および格子 3 の角柱表面では No-slip 条件である。格子 1 の流 入部では、一様流中の解析では $u=1.0 、 v=w=0.0 \quad(u$ : 風方向風速、 $v$ : 風直交方向風速、 $w:$ 鉛直方向風速)、境界層乱流中の解析では $1 / 4$ 勾 配流をターゲットとし 2.2 で示した方法で作成した境界層乱流を与え る。

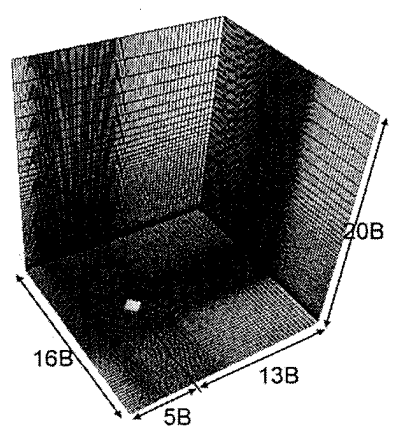

格子 1

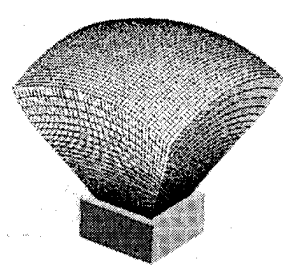

格子 3

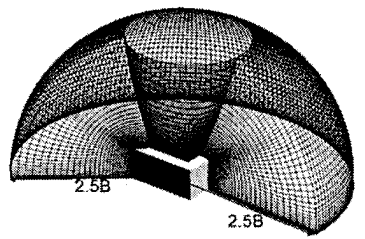

格子 2

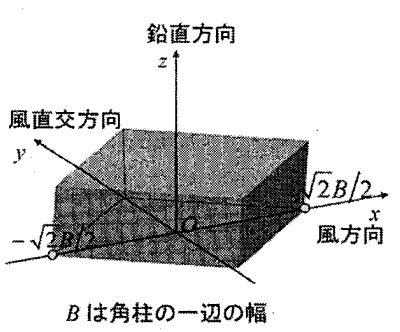

座標軸
図 1 計算格子と座標軸

表 1 格子分割数

\begin{tabular}{|c|c|c|c|}
\hline 格子 1 & 風方向 115 & $\begin{array}{c}\text { 風直交方向 } \\
115\end{array}$ & 鉛直方向 75 \\
\hline 格子 2 & 周方向 201 & 半径方向 50 & 鉛直方向 65 \\
\hline 格子 3 & \multicolumn{2}{|c|}{ 屋根上方の面を $45 \times 45$} & 鈆直方向 50 \\
\hline
\end{tabular}




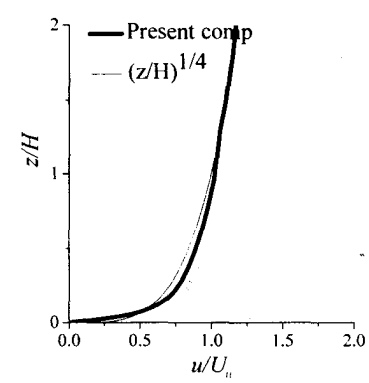

平均風速

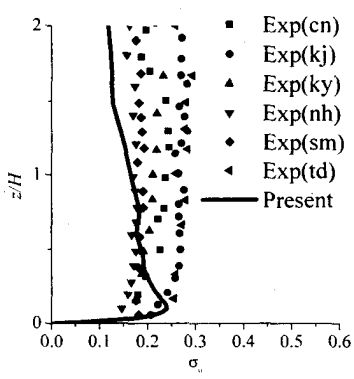

変動風速
図2 本計算で用いる変動流入風

境界層乱流の生成においては、風方向に $32 \mathrm{~B} 、$ 風直交方向に $16 \mathrm{~B}$ 、 鈶直方向に 20B の解析領域を、それぞれ $160 、 80 、 75$ 分割し、風上 から 16B の位置に片岡の方法で用いる抽出断面を設けた。一方、片岡 の方法では、解析領域で摩擦速度が変化しないことを仮定しており、 実験結果と比べると風速が回復するなど、床面付近の予測精度に限界 がある。そこで、文献 21）で示した方法により、16B より風下には ラフネスブロックを設置し、風上から $31 \mathrm{~B}$ 位置の断面の風速を変動流 入風とした。ラフネスブロックの配置に関しては、文献 21）を参照 されたい。本計算で用いる変動流入風を図 2 に示す。上部で乱れの強 さが小さくなっているものの、角柱の高さまでは実験結果のばらつき の範囲にあることが確認できる。

\section{4. 本LES 手法の屋根面風圧予測に対する適用性}

本計算で得られた一様流中および境界層乱流中の屋根面上の風圧 特性を実験結果 16) と比較する。図 3-1、図 3-2 に平均風圧係数挹よ び変動風圧係数のコンター図の本計算結果と実験結果 16 )の比較を示 す。まず一様流中の結果を見てみると、軒先風上で平均風圧係数の最 小值が-2.0 程度、変動風圧係数が 0.25 程度となっており、実験結果 16) とほぼ一致している。また、風下に向かって平均風圧係数の負圧の レベルや変動風圧係数が小さくなる変化の性状に関して計算結果は 実験結果 16) と対応している。境界層乱流中の結果に関しても、平均風 圧係数の最小值が-1.7、変動の最大が 0.5 程度など本計算結果は実験 結果 16) と対応していることが確認できる。一様流中と乱流中の結果を 比較すると、平均風圧倸数は、一様流中のほうが負圧のレベルが高く、 変動風圧係数は境界層乱流中のほうが大きい。図 4 に、軒から $0.05 \mathrm{~B}$ 内側のライン上の平均風王係数の分布の既往の計算結果 16$)$ 、実験結果 16) と本計算結果の比較を示す。既往の計算結果 16)では円錐渦によるラ イン上で負圧レベルがほとんど变化していないが、格子解像度を確保 した本LES解析から、ほぼ実験結果と対応した分布が得られること が確認できる。

次に、屋根風上先端付近の $\mathrm{a} \sim \mathrm{d}$ の点（図 5）における圧力の時刻 歷波形の一様流中と乱流中の比較を図 6 に示す。一様流中のケ一スを 見てみると、無次元時間 $t U D=205$ 付近において圧力特性が急激に変 化している。すなわち、点 $\mathrm{a}$ と点 $\mathrm{d}$ 、点 $\mathrm{b}$ と点 $\mathrm{c}$ の圧力は位相がほぼ 180 度ずれており、屋根面の対角線を中心として両サイドの負圧レべ ルが大きく異なっている。さらに、ある瞬間を境に両サイドでの大き さが入れ替わっていることが判る。また、同じサイドでも軒近傍の点 $a$ (点 $d$ ）と内側の点 $b$ (点 c) では位相が 180 度ずれている。このよ

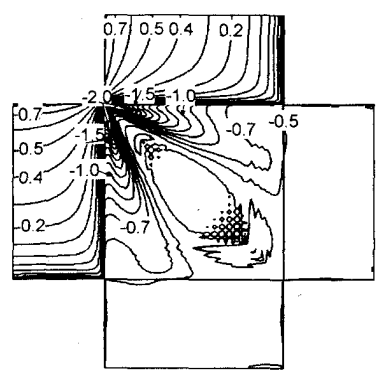

平均風圧係数

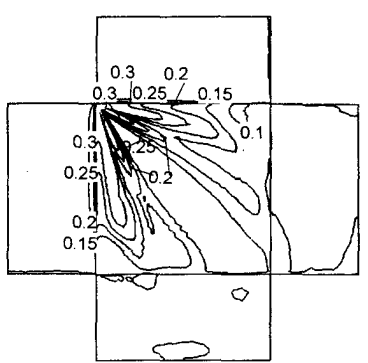

変動風圧係数
本計算結果

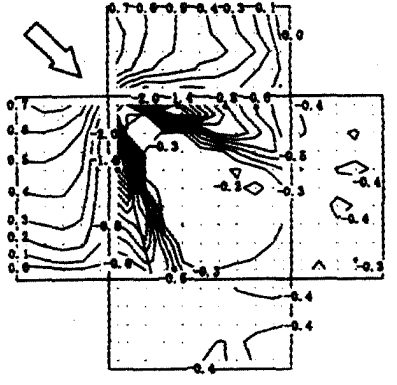

平均風圧係数

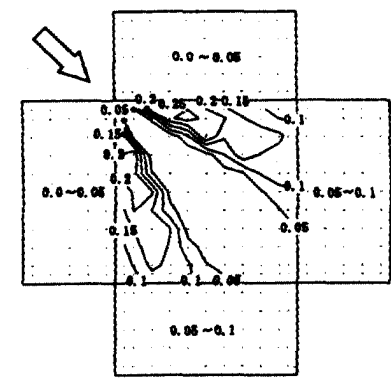

変動風圧係数
実験結果 ${ }^{16)}$

図 3-1 角柱屋根面上の平均および変動風圧係数のコンター図 (一栐流中)
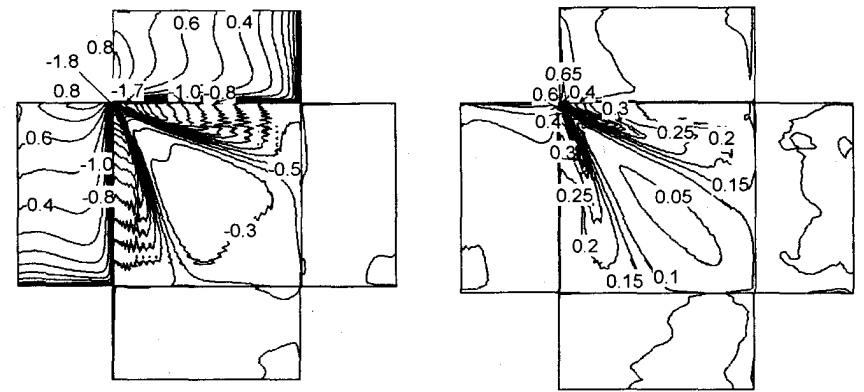

平均風圧係数変動風圧係数 本計算結果

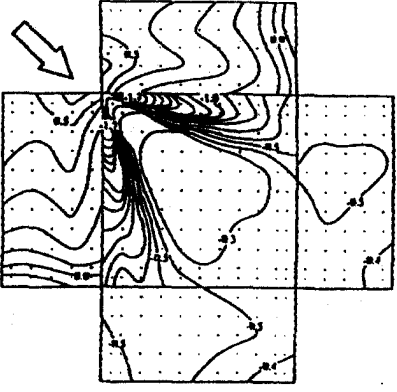

平均風圧係数

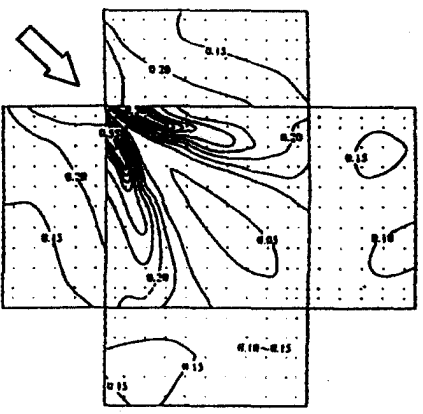

変動風圧係数
実験結果 16$)$

図 3-2 角柱屋根面上の平均および変動風圧係数のコンター図 (境界層乱流中) 


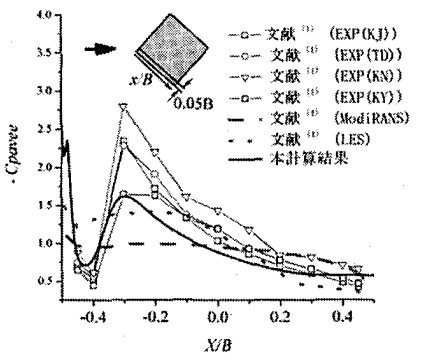

一様流中

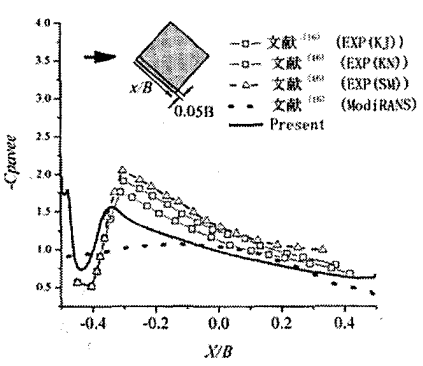

境界層乱流中

図4 軒から0.05B内側のライン上の平均風圧係数の分布 （ただし、図中縦軸は平均風圧係数にー1 を掛けた值）

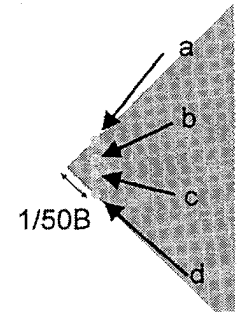

風上先端近傍

図5 圧力の参照点

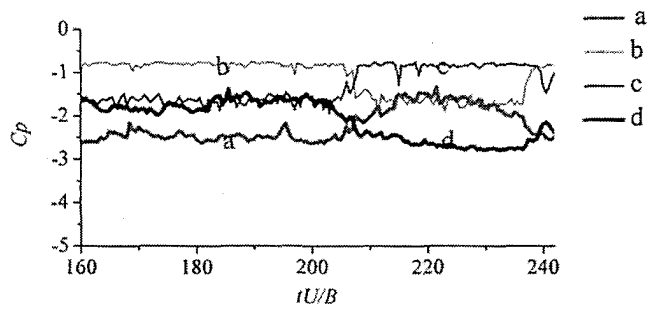

一様流中

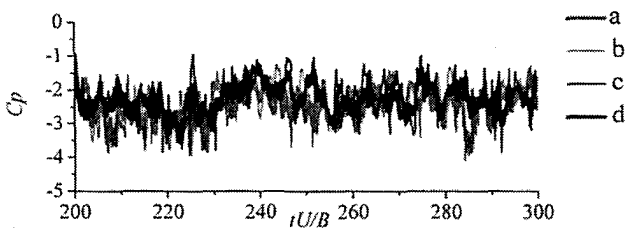

境界層乱流中

図6

風上先端近傍の点 $\mathrm{a} \sim \mathrm{d}$ の風圧係数の時刻歴波形

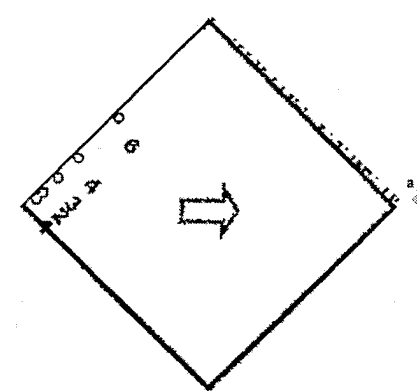

実験結果 7)

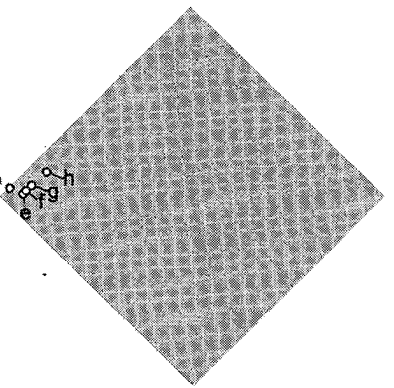

本計算
（1）参照点

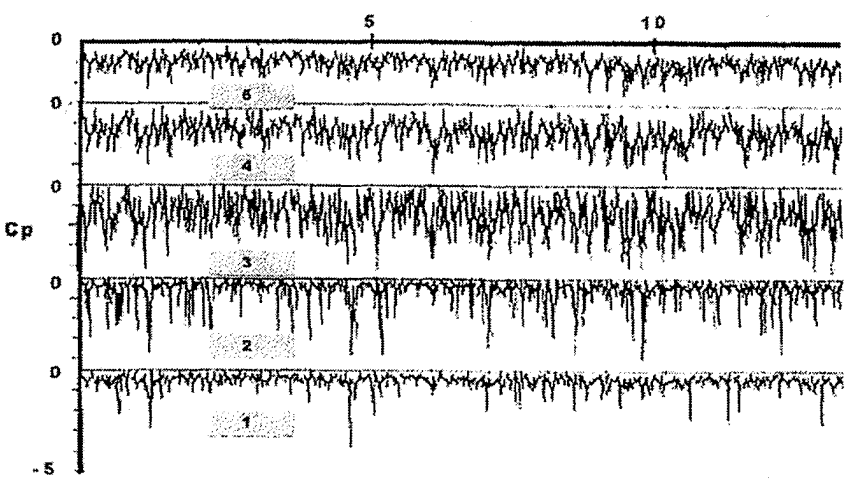

(2) 実験結果 7)
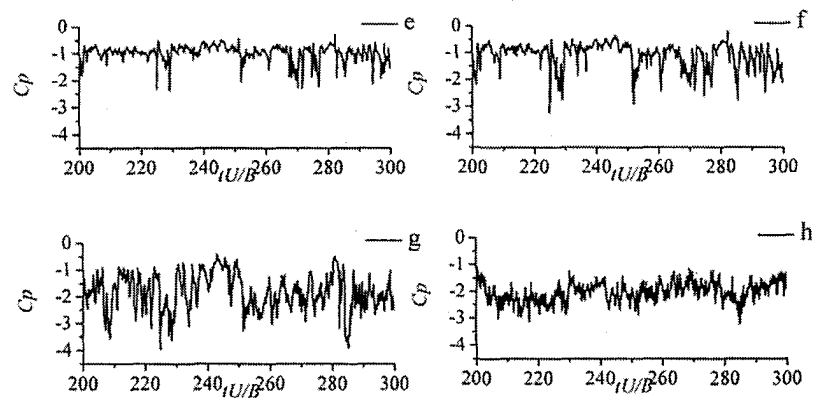

(3) 本計算結果

図7 圧力の時刻歴波形

うな圧力レベルのスイッチは河井らの実験結果りにおいて観測されて いる。一方、境界層乱流中では、既往の実験結果と同様に、圧力レベ ルのスイッチ認められず、瞬間的で強いの負圧のピークが生じている。

図 7 (1)に示守軒から約 $0.05 B$ 内側のラインの点 $\mathrm{e} \sim \mathrm{h}$ における圧力 の時刻暦波形を図 7 (2)(3)に示寸。風上の点 $\mathrm{e}$ では、平均的な負圧のレ ベルは小さく、そして頻度は少ないものの負圧のピークが認められる。 風下に若干離れるに従い点 $\mathrm{f} 、 \mathrm{~g}$ ではピークが頻発し、点 $\mathrm{g}$ では平均 的な負圧のレベルも大きくなる傾向にある。そして、さらに風下の点 $\mathrm{h}$ では大きな負圧のピークはほとんど認められなくなっている。これ らの傾向に関して、本計算結果とKawai7の実験結果は対応している。

図 8 に負圧のレベルが大きく、ピークが頻発した軒先近傍の点 $\mathrm{a}$ と 角柱表面の圧力変動の相互相関係数を示す。一様流中においては、点 $\mathrm{a}$ と同じサイドの A-C 側の軒先近傍の広い領域で相関が高くなってい る。一方、境界層乱流中では軒先 A-C に対してやや傾いた領域で高い 相関が認められる。いずれにせよ、大きな負圧が同時性をもって作用 することが確認できる。 


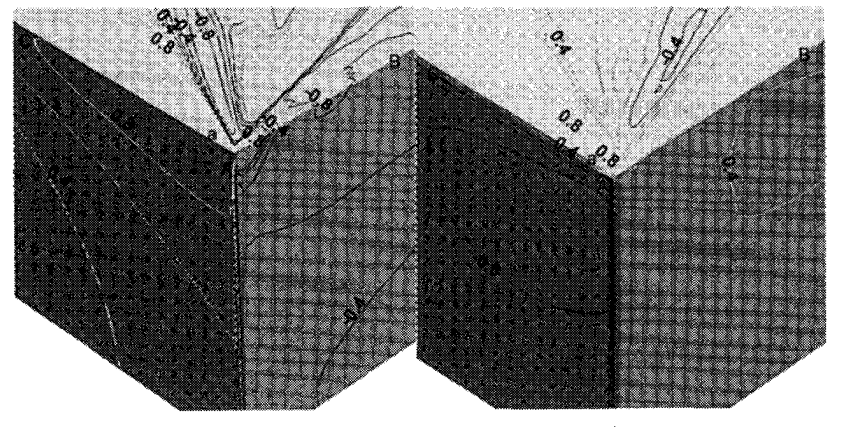

一样流

乱流

図 8 点 $\mathrm{a}$ と角柱表面の風圧変動の相互相関係数

\section{5. 円錐渦と風圧特性の関連性}

4. での本計算結果と実験結果との比較により、本 LES 手法によ り斜めから風が当たった場合の陸屋根まわりの流れへの適用性を検 証した。その際、一様流中においては、軒先の風上領域において負圧 のレベルが屋根面の対角線を挟んで異なり、そしてある瞬間で圧力レ ベルが入れ替わるスイッチングが確認された。一方、境界層乱流中で は、スイッチング現象は認められず、軒先の風上領域に強い負圧のピ ークが同時に作用する現象が認められた。

ここでは、LE S 解析結果を用いて、まず、一様流中における圧力 レベルのスイッチングと円錐渦の挙動との関連性について考察する。 次に、境界層乱流中での円錐渦の挙動を考察し、強いピーク負圧が軒 先に同時に作用する際の流れ特性を検討する。

\section{1 一様流中の圧カレベルのスイッチング}

図 9 に角柱上部の領域における瞬閒渦度 ( $\left.\omega_{x}\right)$ のコンター図を示す。 ただし、 $\omega_{\mathrm{x}}$ は渦度の $\mathrm{x}$ 方向(風方向)成分を示す。本計算により得られ た渦度分布からは、谷口ら 8 が報告する円錐渦の入れ替わりは見られ ず、いずれのサイドでも円錐渦が認められる。

図 10 に(1)〜 (3) に軒先の風上領域の圧力のコンター図と瞬間渦 度のコンター図を示寸。両サイドで円錐渦が確認されるが、詳しく見 ると A-C 側では円錐渦の上側で渦度が乱れ、負圧のレベルが回復して いるのに対し、A-B 側では、円錐渦の乱れは少なく、軒先の風上の広 い領域で負圧のレベルは増加している(1)。その後、両サイドで円錐 渦上部が乱れ (2)、そして、A-B 側の円錐渦の上側のみ乱れ始めた(3)。 それに伴い、A-C 側の軒先の風上近傍の広い範囲で負圧のレベルが上 昇し、A-B 側は回復している。すなわち、風王の強弱が両サイドで入 れ替わる現象が認められた。負圧レベルが上昇しているサイドの円錐 渦の大きさは小さくなっており、これはBanks らの実験結果 ${ }^{12)}$ と対応 する。

さらに、これらの現象の詳細を考察するために、A-B側の負圧のレ ベルが大きい場合の、屋根風上先端領域および屋根面近傍の速度べ クトル図を図 11 、図 12 に示す。また、軒先から発生させたパー ティクル流線図を図 13 に示す。屋根の風上先端ではA-B側において 主流方向に軸を持つより強い循環渦が認められる。一方、上方から見 ると、A-C側の軒先風上領域にz方向（鈆直方向）に軸をもつ反時計周 りの渦（以下 $\omega \mathrm{z}$ 成分を持った渦）が生じている。そして、この渦は 上昇しながら下流に流れ、A-C側で剥離した流れと干涉している。す なわち、一対の円錐渦の間に $\omega_{2}$ 成分を持った渦が存在し、それが片
側の円錐渦と干渉していることが判る。この $\omega_{z}$ 成分を持った渦は、谷 口ら ${ }^{8)}$ によって観測された対角線付近の円錐渦と関連しているものと 思われる。谷口ら ${ }^{8)}$ が報告するように、A-C側では軒からやや風下側 の点Pで流れが分岐し、下流でのみで流線が認められる（図１3）。 谷池 $ら^{9)}$ は、対角線付近の円錐渦の発生要因として、一様流中におけ る風上稜線上の淀み点の不安定性を挙げている。本計算において も、淀み点がA-C側に僅かにずれたときに、屋根面で反時計回りの渦 が発生し、A-C側の円錐渦と干渉している。その結果、A-C側の負圧 レベルは小さくなっている。これらの渦の形成のパターンがA-Bと A-Cとで入れ替わることにより風圧レベルのスイッチが生じている。 一様流中では、この圧カレベルのスイッチに伴い、両サイドで入れ 替わりながら軒先近傍の広い範囲に強い負圧が同時に作用する。

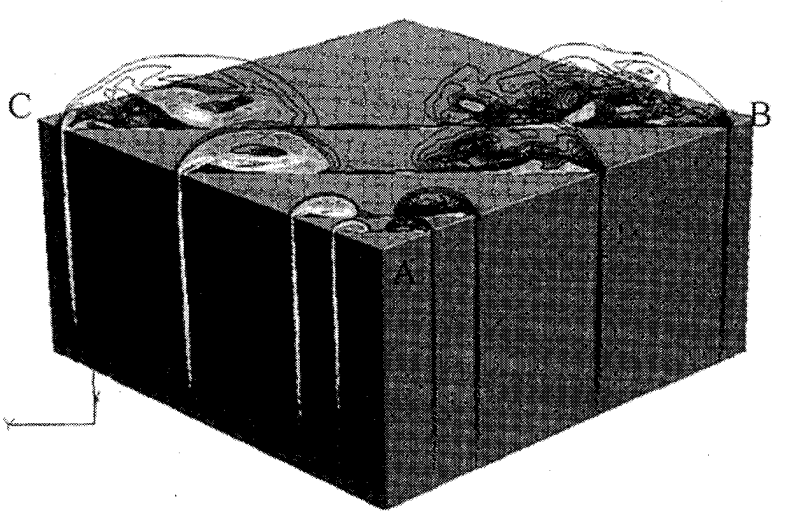

図 9 屋根面上の $\omega \mathrm{x}$ のコンター図（一様流中）

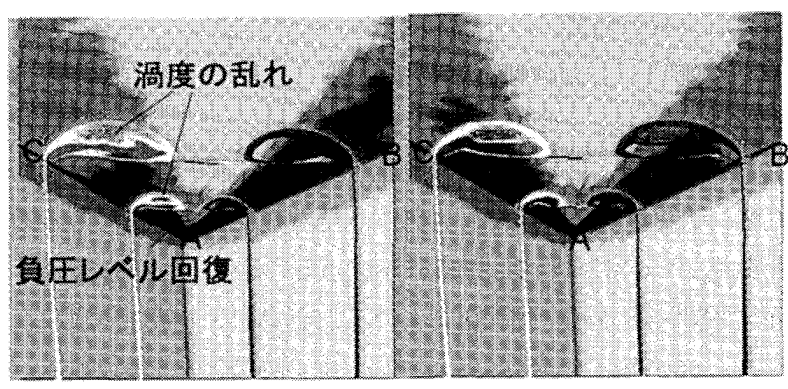

(1)

(2)

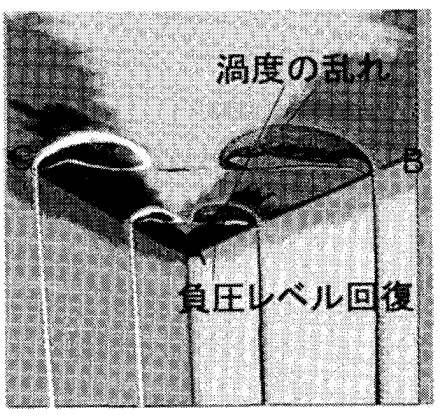

(3)

図 10 軒先近傍の圧力特性と円錐渦の挙動 


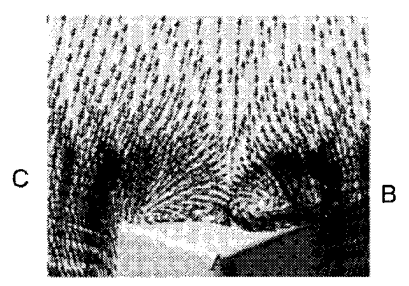

$\mathrm{x} / \mathrm{B}=-0.68$

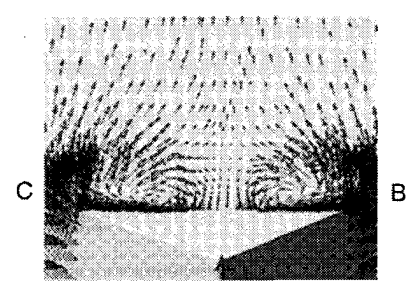

$\mathrm{x} / \mathrm{B}=-0.55$
図 11 軒先近傍の流れ

(yz 方向速度ベクトル図) なお、軒先が $\mathrm{x}=-\sqrt{2} / 2 B$

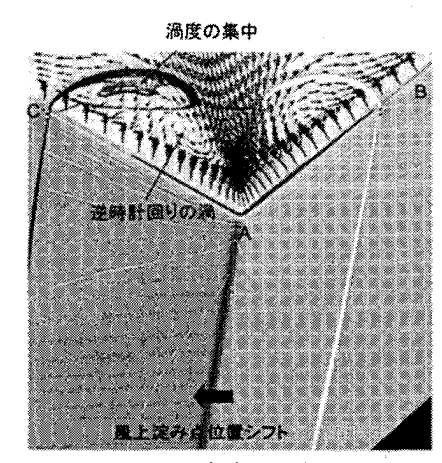

図12 xy 方向速度ベクトル図 $(\mathrm{z} / \mathrm{B}=0.51)$

\section{2 境界層乱流中のピーク負圧}

図6に示したように、風恃係数の時刻歷波形に执いて、境界層乱流 中では圧力レベルのスイッチは認められない。一样流中で認められた 圧カレベルのスイッチは淀み点の位置が風上稜線から片側に僅が シフトした状態が続き、ある瞬間に逆サイドにスイッチすることが要 因となっていた。一方、境界層乱流中では、接近乱流の影響を受け、 淀み点の位置か瀕繁に、一様流中と比べると大きくシフトした (図 1 $4)_{0}$ 。その結果 $\omega_{2}$ 成分を持つ渦は安定して存在せず、一样流中で認め られたような圧力レベルのスイッチが生じなかっものと考えられる。

図6、図7に示したように、境界層乱流中では大きな負圧のピーク が認められた。ここで、本計算により得られた風速、圧力の空間分布 の時刻楚データに执いて、図5に示寸点 a の圧力が-3.5 以下のピーク を示寸瞬間（2 3 回）の風速拉よび圧力を平均し、条件付き流九場を 求めた。図 15 (1)に条件付き平均圧力の等値面図(-2.0)を示す。軒先 の風上近傍領域では円錐渦の中心付近ならびに剥離領域において強 い負圧が認められる。また、図15(2)に示すように軒先風上近傍にお いて Kawai》が報告するように、ピーク負圧が生じるサイドで剥離速 度が増加し、円錐渦のサイズが大きくなっていることが確認できる。

続いて、どのような風が作用したときにピーク負圧が生じるのかを 考察する。図 16 に $z / B=0.51$ および $z / B=0.46$ における条件付き平均速 度べクトル図を示す。ただし、黒知印は 45 度より小さな風向（図中 下向き)、白が 45 度より大きな風向（図中上向き）を示している。負 圧レベルが大きくなっている A-C 側の軒先風上領域を見てみると、速 度ベクトルは黒色を示している。すなわち、点、に大きな負圧が作用 するときには、A-C 側の軒先の風上の広い領域に 45 度以下（図中下 向き）の風向をもつ風が作用していることが判る。

このピーク負圧発生時の風向特性や軒先の広い領域に安定した風 が作用する現象は、Kawai》が示している風上の参照点の流れ特性、
すなわちスケールが大きい乱れが斜め 25 度付近から作用する特性と 対応している。

次に、本計算結果に基づきピーク負圧発生時の屋根近傍における流 れ場を見てみる。図 17 亿点 $\mathrm{a}$ の圧力変動 $\mathrm{p}$ ' と風直交方向の風速変 動 v'および鉛直方向の風速変動 w'の相互相関係数が 0.5 の等值面図を 示す。稜線 $\mathrm{A}-\mathrm{D}$ および $\mathrm{A}-\mathrm{C}$ 側の軒先の風上の広い領域で風直交方向 の風速変動と点 $\mathrm{a}$ の圧力変動が高い相関を示している。鉛直方向の風 速变動に関しては、A-C 側の軒先の剥離領域での相関が高くなってい る。図8に示したように点 $\mathrm{a}$ と同じサイド (A-C 側) の側面の圧力変 動の相関は負の相関となっている。すなわち、ピーク負圧発生時に側 面の正圧が上昇し、屋根面との圧力差が大きくなり、剥離領域での速 度が増加している現象が確認できる。このようにKawai》が報告して いる、ピーク負圧発生時に大きなスケールの乱れが軒先に対して、よ り正対する風向から当たり、側面の正圧が上昇し、屋根面上への剥離 速度が増加する現象が、本計算結果から確認できる。また、本計算結 果による空間構造(図 1 7)から、ピーク負圧発生時には軒先のかなり 広い範囲で剥離速度の増加か認められる。そのため、図 15 5(1)を見て みるとピーク負圧発生時には円錐渦の中心の負圧レベルの増加が軒 先風上付近ばかりではなく後方まで生じている。この円錐渦の影響を 受け風上軒先から下流に向けて、ピーク負圧が同時に作用するものと 考えられる。

一方、図 7 の点 $\mathrm{e}$ 、点 $\mathrm{f}$ の時刻暦波形において負圧のピークがより 間欠的となっている。点 $\mathrm{e}$ の時刻暦波形に执いてピークが-2 以下を示 した瞬間の平均速度ベクトル図を図 18 亿示す。点 $\mathrm{e}$ でピーク負圧が 発生する場合には、点 a のケース (図 1 5(2)) と比べると円錐渦の少 イズがかなり大きくなっている。すなわち、風上の軒先近傍でピーク 負圧が発生する際には円錐渦のサイズが増加する傾向があるが、その 都度大きさは異なっており、大きな円錐渦が発生した場合に負圧の発 生領域が広がり、軒先から離れた平均的に負圧レベルが小さい領域で も瞬間的に負圧レベルが大きくなり、間欠的なピーク負圧が発生する ものと考えられる。

したがって、本計算により得られた境界層乱流中の円錐渦のサイズ と風圧特性の関倸は、Kawai(7) と同様に、ピーク負圧発生時には円錐 渦のサイズは大きくなる傾向がある。ただし、その都度サイズは異な り、円錐渦のサイズと圧カレベルの相関は得られなかった。これは Banks ら(12)の報告と同様である。

以上、一様流中と境界層乱流中に执て、それぞれの強い負圧をも たらす現象について考察した結果、いずれのケースも淀み点の移動に より、冈錐渦の特性が変化することが確認された。ただし、現象は一 様流中と乱流中で大きく異なり、淀み点の位置と負圧が生じるサイド の関係が逆になる。図8に示した点 $\mathrm{a}$ と表面の圧力変動の相互相関係 数を見てみると、境界層乱流中では、正圧が大きくなったサイドと同 じサイドの屋根面に強い内錐渦が形成され、負圧レベルが大きくなる (負の相関)。一方、一様流中で生じたスイッチングにおける強い負 圧発生時には、淀み点がシフトし正圧が大きくなったサイドと中心線 を挟んで逆側の屋根面の負圧レベルが増加する。淀み点と同じサイド では負圧は回復するため、点 $\mathrm{a}$ と同じサイドの側面の圧力変動の相関 は高い。 


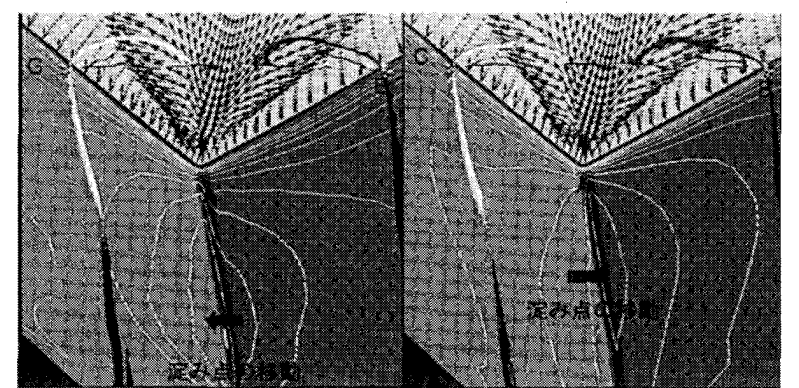

図 14 境界層乱流中での軒先付近流れ場 角柱側面の風区係数の分布 および/B=0.51におうける速度べクトル図

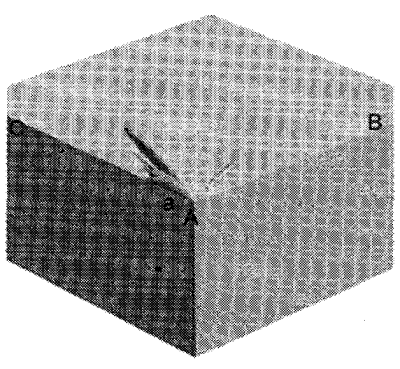

（1）圧力の等値面図 $(-2.0)$

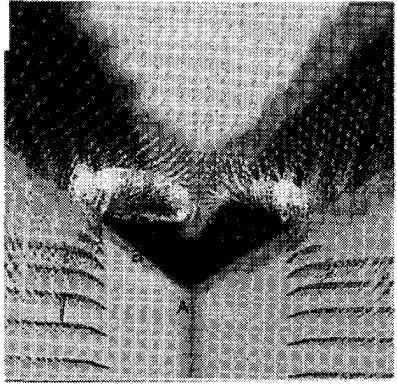

(2)yz 方向速度ベクトル $(\mathrm{x} / \mathrm{B}=0.65)$ なお、軒先が $\mathrm{x}=-\sqrt{2} / 2 B$

図 15 条件付き流れ場 (点 $\mathrm{a}$ の圧力が-3.5 以下のピーク時の平均)

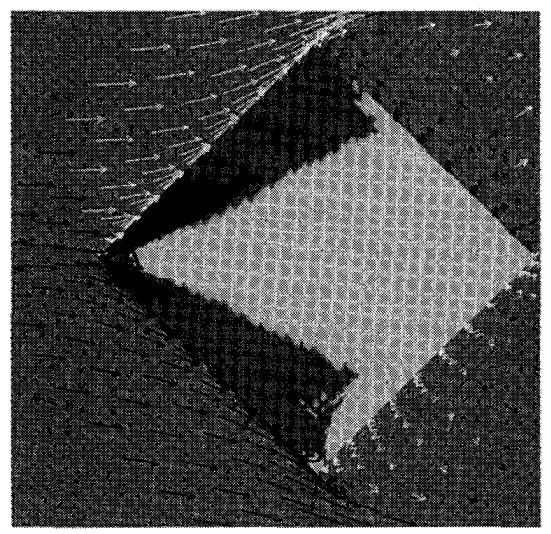

$\mathrm{z} / \mathrm{B}=0.46$

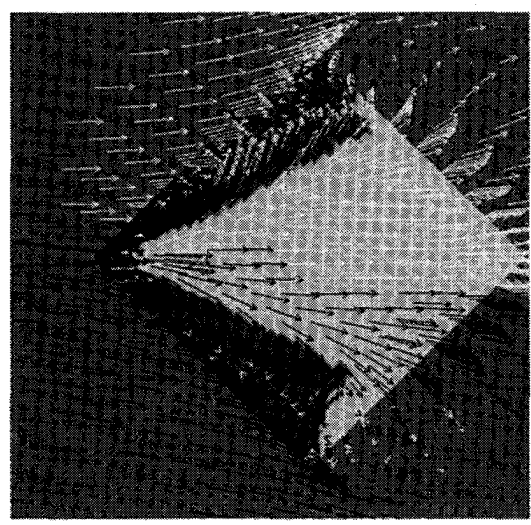

$\mathrm{z} / \mathrm{B}=0.51$

図 16 条件付き平均速度ベクトル図 (点 $\mathrm{a}$ の圧力が-3.5 以下のピーク時の平均)
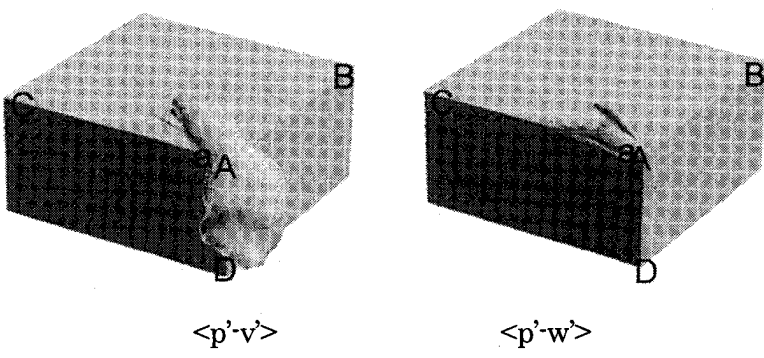

$\langle$ p'w'>

図 17 点a の圧力変動と周辺の風速変動の 相互相関係数の等值面図（相互相関係数が 0.5）

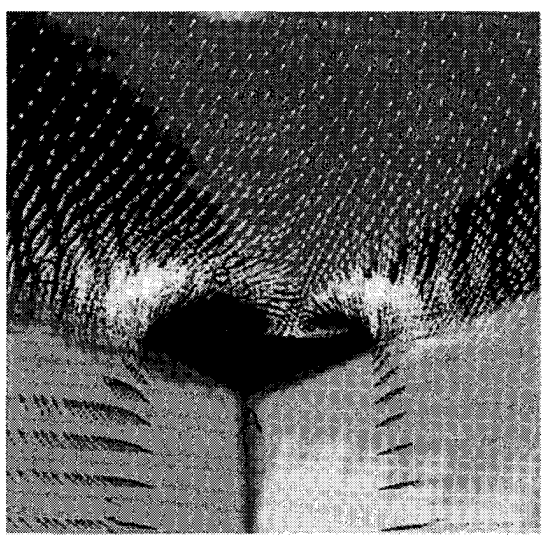

図18 ピーク負圧時の流れ

アンサンブル平均（表面風圧係数のコンター図および速度ベクト 儿図)

\section{6. 結論}

本研究では、風が斜め 45 度から陸屋根に当たった時に生じる強い 負圧と円錐渦の挙動との関連性を明らかにすることを目的とし、低層 構造物まわりの流れの LES 解析を行った。まず、一様流中および境 界層乱流中の 1:1:0.5 の角柱の屋根面の風圧特性に関して、計算結果 と実験結果と比較し、本 LES 手法の適用性を検証した。次に、既往 の研究で観測されている一様流中において屋根面の対角線を挟んだ 両サイドで圧力レベルが入れ替わる現象や境界層乱流中で強い負圧 が生じる現象について円錐渦の挙動に基づき検討した。

得られた知見を以下に示す。

1 . 一様流中および境界層乱流中における 1:1:0.5 の角柱屋根面の 風圧係数に関して、本計算結果と既往の実験結果 16) と比較を 行ったところ、平均風圧係数、変動風圧係数ともに対応するこ とを確認した。

2. 本計算で得られた軒先近傍の点の時刻歴波形から、一様流中で は屋根面対角線を挟む両サイドで圧力レベルが異なり、ある瞬 間それが入れ替わる圧力レベルのスイッチングを確認した。境 界層乱流中では圧力レベルのスイッチは生じず強い負圧が生 じた。

3. 屋根面の相互相関係数の分布から、一様流中においては、軒先 の広い領域で強い負圧が同時に作用することが確認された。ま 
た、境界層乱流中では軒先風上の軒に対してやや傾いた領域で ピーク負圧が同時に作用することを確認した。

4. 一様流中において、圧カレベルのスイッチング現象について考 察した。その結果、一様流中で風上稜線上の淀み点が僅かにサ イドにシフトした状態が続く際に、屋根面上に鈆直方向に軸を もつ渦が形成され、片側の円錐渦之干渉する現象が認められた。 この渦と干渉するサイドの円錐渦は乱され圧カレベルは回復 するのに対し、逆サイドの円錐渦はサイズが小さく軒先の広い 領域で負圧レベルが大きくなったここの現象が両サイドで入れ 替わることにより圧力レベルのスイッチが生じるものと考え られる。一様流中における円錐渦のサイズと圧カレベルの関係 は Banks ら 10)の報告と同様である。

5. 乱流中においては、接近乱流の影響を受け淀み点が頻繁に左右 に大きくシフトした。そのため、屋根面に鉛直方向に軸を持つ 渦が安定して形成されず、圧カレベルのスイッチは生じないも のと考えられる。

6. 境界層乱流中で軒先に強い負圧のピークが生じる現象につい

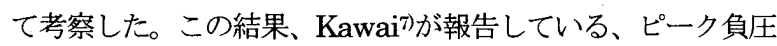
発生時には、大きなスケールの乱れが軒に、より正対する風向 から当たり、側面の正圧が上昇し屋根面への剥離速度が増加す る現象が、本計算で得られた流れ場からも確認された。

7. 本計算結果による流れの空間構造から、ピーク負圧発生時には 軒のかなり広い範囲で剥離速度の増加し、円錐渦の中心の負圧 レベルの増加が軒先風上付近ばかりではなく後方まで生じた。 この円錐渦の影響を受け風上軒先から下流に向けて、ピーク負 圧が同時に作用するものと考えられる。

8. 軒から離れた位置で認められた閒欠的なピーク負圧の発生に 要因ついて考察を行った。その結果、軒先近傍でピーク負圧が 発生する際には円錐渦のサイズが増加する傾向があるが、その 都度大きさは異なっており、大きな円錐渦が発生した場合に負 圧の発生領域が広がり、軒先から離れた平均的に負圧レベルが 小さい領域において、瞬間的に負圧レベルが大きくなり、間欠 的なピーク負圧が発生するものと考えられる。

9.一様流中で生じたスイッチングにおける強い負圧発生時には、 淀み点がシフトし正圧が大きくなったサイドと中心線を挟ん で逆側の屋根面の負圧レベルが増加する。一方、境界層乱流中 の強い負圧の発生時には、風向変化により淀み点が移動し正圧 が大きくなったサイドと同じサイドの屋根面の負圧レベルが 大きくなる。

\section{考文献}

1) H.W.Tieleman: Problem associated with flow modeling precedured for low-rise structures, J. Wind. Eng. Ind. Aerodyn, Vol.41-44, pp923-934, 1992.

2) 河井宏允, 西村元吾, 草柳拓人, 陸屋根上の円錐渦と風圧変動につい, 第13回風工 学シンポジウム, 149-154, 1994.

3) H. Kawai, G. Nishimura, Characteristics of fluctuating suction and conical vortices on a flat roof in oblique flow, J. Wind. Eng. Ind. Aerodyn, Vol.60, pp211-225, 1996.

4) Kawai, Structure of conical vortices related with suction fluctuation on a flat roof in oblique smooth and turbulent flows, J. Wind. Eng. Ind. Aerodyn, Vol.69-71, pp579-588, 1997.

5) 河井宏允,陸屋根に作用寸る風圧変動特性について-風圧変動の同時測定結果-, 第14 回風工学シンポジウム, 557-562, 1996.

6) H.Kawai, F.Ohnuma, Peak suction and conical vortex on a flat roof, Proceeding of the $10^{\text {th }} \mathrm{In}$ ternational Conference on Wind Engineering, pp1807-1812, 1999.

7) H.Kawai, Local peak pressure and conical vortex on building, J. Wind. Eng. Ind. Aerodyn, Vol.90, pp251-263, 2002.

8) 谷口徹郎, 谷池義人，陸屋根面上の円錐渦に関する可視化風洞実験，日本建築学会 構造系論文集，第488号, pp31-37, 1996.

9) 谷池義人, 谷口徹郎, 両角達郎, 種々の陸屋根面上に形成される冈錐渦のスイッチ ング現象解析，第15回風工学シンポジウム, 305-310, 1998.

10) 谷池義人, 谷口徹郎, 武平俊秀, 奥田上総, 自然風中における立方体建物に作用す る風圧特性，第16回風工学シンポジウム,pp321-326, 2000.

11) R.Marwood, C.J.Wood, Conical vortex movement and its effect on roof pressure, J. Wind. Eng. Ind. Aerodyn, Vol.69-71, pp589-588, 1997.

12) D. Banks, R. N. Meroney, P. P. Sarkar, Z. Zhao, F. Wu, Flow visualization of conical vortices on flat roofs with simultaneous surface pressure measurement, Journal of Wind Eng. and Industrial Aerodynamics,84, pp65-85, 2000.

13) 小野 佳之, 田村哲郎: 角柱の空力不安定振動に及ぼす乱流効果に関するLES解析, 日本建築学会構造系論文集, No563, pp67-74, 2003-1.

14) 小野 佳之, 田村哲郎: 三次元円柱の渦励振現象に関寸るLE S 解析, 日本建築学 会構造系論文集, $581, \mathrm{pp} 7-14,20047$.

15) 小野 佳之, 田村哲郎：高層タワーの渦厉振問題へのL E S の適用と展開，日本建 築学会構造系論文集, 592,pp35-42,2005-6.

16）日本建築学会耐風設計資料小委員会，流体計算と風荷重評価，1994.11.

17) 梶島 岳夫, 対流項の差分形式とその保存性，日本機械学会論文集 (B編), 60-574, B, pp.186-191, 1994.

18) Y. Ono, T. Tamura, Large eddy simulation using a curvilinear coordinate system for the flow around a square cylinder, Wind \& Structure, Vol5, No2, pp369-378, 2002.

19) T. S. Lund, X. Wu , and K. D. Squires, Generation of turbulent inflow data for spatially-developing boundary layer simulations, J. Comp. Phys., 140, pp.233-258, 1998.

20) 片岡 浩人, 水野 稳 流入変動風を用いた三次元角柱周り流れの計算一平均速度 分布を与条件とした流入変動風の作成方法について一, 第12回 数值流体力学シ ンポジウム,pp.173-174, 1998.

21）小野佳之, 田村哲郎, 粗面を有する三次元丘陵地まわりの強風乱流入のLESの適用, 日本建築学会構造系論文集, 第606号,pp873-880, 2006-8.

(2007年 6 月 8 日原稿受理， 2007 年 8 月 3 日採用決定) 